\title{
Studie- en beroepskeuzevoorlichting en arbeidsmarktinformatie: voorstellen voor een onderzoekprogramma
}

Citation for published version (APA):

Teunis, U., \& van der Velden, R. K. W. (1996). Studie- en beroepskeuzevoorlichting en arbeidsmarktinformatie: voorstellen voor een onderzoekprogramma. Researchcentrum voor Onderwijs en Arbeidsmarkt, Faculteit der Economische Wetenschappen. ROA Working Papers No. 6 https://doi.org/10.26481/umarow.1996006

Document status and date:

Published: 01/01/1996

DOI:

10.26481/umarow.1996006

Document Version:

Publisher's PDF, also known as Version of record

Please check the document version of this publication:

- A submitted manuscript is the version of the article upon submission and before peer-review. There can be important differences between the submitted version and the official published version of record.

People interested in the research are advised to contact the author for the final version of the publication, or visit the DOI to the publisher's website.

- The final author version and the galley proof are versions of the publication after peer review.

- The final published version features the final layout of the paper including the volume, issue and page numbers.

Link to publication

\footnotetext{
General rights rights.

- You may freely distribute the URL identifying the publication in the public portal. please follow below link for the End User Agreement:

www.umlib.nl/taverne-license

Take down policy

If you believe that this document breaches copyright please contact us at:

repository@maastrichtuniversity.nl

providing details and we will investigate your claim.
}

Copyright and moral rights for the publications made accessible in the public portal are retained by the authors and/or other copyright owners and it is a condition of accessing publications that users recognise and abide by the legal requirements associated with these

- Users may download and print one copy of any publication from the public portal for the purpose of private study or research.

- You may not further distribute the material or use it for any profit-making activity or commercial gain

If the publication is distributed under the terms of Article $25 \mathrm{fa}$ of the Dutch Copyright Act, indicated by the "Taverne" license above, 
Studie- en beroepskeuzevoorlichting en arbeidsmarktinformatie: voorstellen voor een onderzoeksprogramma

ROA-W-1996/6

U. Teunis en R.K.W. van der Velden

Researchcentrum voor Onderwijs en Arbeidsmarkt

Faculteit der Economische Wetenschappen en Bedrijfskunde Universiteit Maastricht

Maastricht, oktober 1996 
ISBN 90-5321-196-9 


\section{Inhoud}

\section{Bladzijde}

1 Inleiding 1

2 Samenvatting uitkomsten literatuurstudie $\quad 4$

2.1 Samenvatting bevindingen 4

2.2 Aangrijpingspunten voor evaluatie 6

3 Deelprogramma 1: Effecten 12

3.1 Vijf voorstellen $\quad 12$

3.2 Dekking effectmaten $\quad 19$

4 Deelprogramma 2: Veranderende omgeving 21

4.1 Aanleiding 21

4.2 Conceptueel kader $\quad 23$

4.3 Onderzoeksvoorstellen $\quad 24$

5 Synthetiserend rapport $\quad 27$

$\begin{array}{lr}\text { Literatuur } & 27\end{array}$ 


\section{Inleiding}

In 1995 en 1996 heeft het ROA de literatuurstudie 'studie- en beroepskeuzevoorlichting: het effect van arbeidsmarktinformatie' uitgevoerd. Aanleiding tot deze studie was de vraag naar de evalueerbaarheid van de effecten van studie- en beroepskeuzevoorlichting, en in dat kader van arbeidsmarktinformatie, op het keuzegedrag van leerlingen en studenten. De literatuurstudie leverde meer in het algemeen een overzicht van recente ontwikkelingen in (het denken over) de studie- en beroepskeuzevoorlichting op. Het ROA achtte dit overzicht van zelfstandige betekenis, gezien de actualiteit van een aantal ontwikkelingen met betrekking tot de studieen beroepskeuzevoorlichting en de mogelijke waarde van het overzicht voor de beleidsbepaling aan de kant van de opdrachtgever (het ministerie van Onderwijs, Cultuur en Wetenschappen, directie Beroepsonderwijs en Volwassenen Educatie BVE). Daarom heeft het ROA dit overzicht afzonderlijk als rapport gepubliceerd".

Het oorspronkelijke doel van de literatuurstudie was echter niet het bieden van een actueel overzicht, maar het verkennen van de mogelijkheden tot onderzoek naar de effecten van arbeidsmarktinformatie en de processen die bij het genereren van deze effecten een rol spelen. Deze mogelijkheden worden in dit werkdocument thans afzonderlijk gepresenteerd. Dit geschiedt in de vorm van een voorstel voor een onderzoeksprogramma 'Studie- en beroepskeuzevoorlichting en arbeidsmarktinformatie'.

\section{Vraagstelling}

De vraagstelling van het totale onderzoeksprogramma luidt: onder welke voorwaarden kan studie- en beroepskeuzevoorlichting, en in dat kader in het bijzonder arbeidsmarktinformatie, een bijdrage leveren aan een verbetering van het allocatieproces op de arbeidsmarkt, gegeven veranderingen in de maatschappelijke en economische omgeving enerzijds en in de institutionele structuur betreffende studie- en beroepskeuzevoorlichting anderzijds? Het optimaliseren van het allocatieproces door middel van arbeidsmarktinformatie kan via verschillende kanten bereikt worden. Enerzijds kan het betrekken van arbeidsmarktinformatie bij de studie- en beroepskeuze leiden tot een rationelere en beter onderbouwde keuze van individuen, een keuze die tot minder 'spijt achteraf' leidt. Anderzijds kan informatie over de voor bepaalde beroepen benodigde kwalificaties leiden tot een betere ontwikkeling van de capaciteiten van individuen en een betere allocatie van talenten. Beantwoording van de centrale vraagstelling vereist enerzijds nader inzicht in de 'werking' van studie- en beroepskeuzevoorlichting en arbeidsmarktinformatie, dus in het effect en in de voorwaarden tot verbetering van de effectiviteit. Anderzijds gaat het om veranderingen in de maatschappelijke, economische en institutionele 'omgeving', die zowel leiden tot andere eisen aan als tot zich wijzigende condities voor studie- en beroepskeuzevoorlichting. Het uiteindelijk belang van het programma als geheel betreft de mogelijkheden

1. U. Teunis, Studie- en Beroepskeuzevoorlichting: het effect van arbeidsmarktinformatie, ROA-R1996/4, juni 1996. 
tot verbetering van aanbod en vormgeving en van de effectiviteit van de arbeidsmarktinformatie in relatie tot de inrichting van de studie- en beroepskeuzevoorlichting, gegeven de eisen vanuit de 'omgeving'; het gaat uiteindelijk om behoud en verbetering van de relevantie van deze informatie onder zich wijzigende omstandigheden. Gegeven dit belang omvat het programma niet alleen het vermeerderen en compileren van kennis ter zake maar ook het formuleren van een visie op het geheel.

\section{Deelprogramma's en synthetiserend rapport}

Uit de in het voorgaande geschetste vraagstelling komen twee invalshoeken voor het formuleren van onderzoeksvoorstellen naar voren: die betreffende de vormgeving en effecten van studie- en beroepskeuzevoorlichting, en in het bijzonder van arbeidsmarktinformatie, en die betreffende de veranderende omgeving. Deze twee invalshoeken worden in het programmavoorstel vertaald in twee deelprogramma's, 'effecten' en 'veranderende omgeving'. Het onderscheid tussen deze invalshoeken, en dus tussen de deelprogramma's, is echter betrekkelijk; het ROA pleit nadrukkelijk voor een uiteindelijke synthese van de bevindingen met het oog op een nieuwe visie op studie- en beroepskeuzevoorlichting en de rol van arbeidsmarktinformatie.

Het eerste deelprogramma 'effecten' betreft in directe zin de effecten van studie- en beroepskeuzevoorlichting, en in het bijzonder arbeidsmarktinformatie, en de mogelijkheden tot verbetering van de effectiviteit. Dit onderzoek sluit aan op de in te literatuurstudie aangetroffen effectmaten. De nadruk ligt op de feitelijke meting van effecten van studie- en beroepskeuzevoorlichting en arbeidsmarktinformatie; het gaat dus om empirisch onderzoek en om de effecten binnen de gegeven institutionele context. Dit deelprogramma omvat vijf onderzoeksvoorstellen.

Het tweede deelprogramma 'veranderende omgeving' betreft de actuele veranderingen in de 'omgeving', maar vooral ook de verwachtingen voor de nabije en verdere toekomst. 'Omgeving' betreft hier enerzijds de institutionele structuur waarbinnen studie- en beroepskeuzevoorlichting vorm krijgt en arbeidsmarktinformatie al dan niet wordt gebruikt; anderzijds gaat het om veranderingen in de maatschappelijke en economische context die zowel de vraag naar deze informatie als de mogelijke effectiviteit ervan beïnvloeden. Dit onderzoek betreft dus vooral het in kaart brengen van de veranderingstendensen binnen deze contexten en het documenteren en waarderen van de verwachtingen voor de nabije en wat verdere toekomst. Dit deelprogramma omvat drie onderzoeksvoorstellen.

Verbindend element tussen beide deelprogramma's is de achterliggende theorievorming en de daaruit voortkomende vraagstelling en het streven naar een synthese van kennis en visies. Voorgesteld wordt deze synthese tot stand te brengen in een afzonderlijk rapport, waarin de nadruk ligt op het formuleren van een overkoepelende visie op basis van empirische gegevens en verwachtingen voor de toekomst. De uitkomsten van beide deelprogramma's worden in dit rapport op elkaar betrokken vanuit de vraagstelling naar de voorwaarden voor een grotere 
effectiviteit van studie- en beroepskeuzevoorlichting en arbeidsinformatie, gegeven een veranderende omgeving. Op basis van een nieuwe visie kunnen beleidsmatige aanbevelingen en aanbevelingen aangaande verder onderzoek worden gegeven.

\section{Leeswijzer}

In hoofdstuk twee worden de bevindingen van de eerdergenoemde literatuurstudie globaal samengevat (paragraaf 2.1). Daar waar de literatuurstudie ingaat op de veronderstelde effecten van studie- en beroepskeuzevoorlichting, die mogelijk aanknopingspunten kunnen bieden voor evaluatie, worden de bevindingen vrijwel integraal weergegeven; waar mogelijk worden de gevonden effecten nader uitgeschreven in de richting van operationaliseerbare effectvariabelen (paragraaf 2.2). Deze vormen de grondslag voor de onderzoeksvoorstellen in het eerste deelprogramma. De in het literatuurrapport gesignaleerde trends in de 'omgeving' van de studie- en beroepskeuzevoorlichting vormen de achtergrond voor de voorstellen in tweede deelprogramma.

In hoofdstuk 3 wordt het eerste deelprogramma 'effecten' gepresenteerd. In paragraaf 3.1 worden vijf onderzoeksvoorstellen gepresenteerd. In paragraaf 3.2 wordt de 'dekking' van de in de literatuurstudie gevonden effectvariabelen door de verschillende onderzoeken nader aangegeven.

In hoofdstuk vier wordt het tweede deelprogramma gepresenteerd. In paragraaf 4.1 worden de constateringen uit het literatuurrapport aangehaald die tot dit deelprogramma aanleiding hebben gegeven. In paragraaf 4.2 wordt een conceptueel kader gepresenteerd. In paragraaf 4.3 worden drie onderzoeken voorgesteld.

In hoofdstuk vijf tot slot wordt het voorstel voor het synthetiserend rapport nader uitgewerkt.

\section{Definities}

Onder 'studie-en beroepskeuzevoorlichting' wordt in dit werkdocument, in aansluiting op de literatuurstudie, een complex van institutionele processen in relatie tot de overgang van het onderwijssysteem naar het arbeidsleven samengevat, in het bijzonder voorlichting in eigenlijke zin, onderzoek naar aanleg en capaciteiten ('testen'), advisering, individuele en groepsgewijze begeleiding, kennisoverdracht, ontwikkeling van relevante keuze- en loopbaancompetenties en dergelijke. Dit complex omvat dus veel meer dan 'voorlichting', maar de term wordt hier als overkoepelende aanduiding gebruikt. In voorkomende gevallen worden nadere specificaties gebruikt. Onder 'arbeidsmarktinformatie' wordt hier verstaan alle informatie betreffende de mogelijke gevolgen van keuzes voor de positie bij het feitelijk betreden van de arbeidsmarkt en bij veranderingen in de beroepsloopbaan. Arbeidsmarktinformatie in deze zin omvat altijd een element van prognose om de tijdsinterval tussen moment van keuze en de effecten van die keuze bij het betreden van de arbeidsmarkt of anderszins te overbruggen. 
In het tot stand komen van dit werkdocument is een actieve bijdrage geleverd door dr. L. Borghans, dr. A. De Grip en prof. dr. J.A.M. Heijke. De twee eerstgenoemde hebben vooral een bijdrage geleverd aan de ideeënvorming rond het eerste deelprogramma; van de heer Heijke is een aantal ideeën gekomen die mede ten grondslag liggen aan het tweede deelprogramma en het synthetiserend rapport.

\section{Samenvatting uitkomsten literatuurstudie}

\subsection{Samenvatting bevindingen}

\section{Historische ontwikkeling}

De literatuurstudie start met een schets van de historische ontwikkeling van de studie- en beroepskeuzevoorlichting in Nederland ${ }^{2}$. De professionele beroepskeuzevoorlichting ontwikkelt zich geleidelijk vanaf het begin van deze eeuw. Aanvankelijk lag de nadruk op advisering aangaande de geschiktheid voor een beroep op basis van lichamelijke en psychische kenmerken van het individu. Het lichamelijke aspect raakte reeds voor de Tweede Wereldoorlog op de achtergrond; advisering op basis van een psychometrische benadering werd het dominante beroepsbeeld. Een andere constante was het paternalistische model, waarbij het geven van een gezaghebbend advies centraal stond. Een breuk in deze geleidelijke ontwikkeling ligt rond 1960. Daarna verschuift de nadruk van 'geschiktheid' naar 'authenticiteit' en 'zelfbepaling': de ontdekking van het 'zelf' als grondslag van de advisering. Na 1970 verschuift de nadruk bovendien van advies naar begeleiding van de eigen keuzes van de cliënt. Een tweede breuklijn wordt geconstateerd rond 1980, in verband met de sterk toenemende (jeugd)werkloosheid. Er ontstaat dan een tweedeling in het denken over studie- en beroepskeuzevoorlichting. Enerzijds benadrukken de overheid, werkgevers, de SER e.a. sterk de noodzaak van arbeidsmarktrelevante studie- en beroepskeuzes en daarop gerichte voorlichting en begeleiding. Anderzijds houdt de beroepsgroep van professionele adviseurs nog lange tijd vast aan het in de jaren ' 60 en '70 gevormde beroepsbeeld, waarin zelfontdekking en zelfontplooïng centraal staan. Deze tegenstelling lijkt ook het geconstateerde verschil in theoretische benadering van de studie- en beroepskeuzevoorlichting te verklaren.

\section{Twee benaderingen}

De literatuurstudie stelt vast dat in het denken over studie- en beroepskeuzevoorlichting in hoofdlijn twee benaderingen zijn aan te treffen. Deze worden in verband gebracht met de tegenstelling in denken die in de jaren '80 ontstond (zie boven) en met de verschillende

2. Deze schets is vooral gebaseerd op: Pere, H.M., Tussen arbeidsmarkt en individueel welzijn; een historische analyse van de beroepskeuzevoorlichting in Nederland vanuit beroepensociologisch perspectief, Educaboek, Culemborg 1986. 
disciplinematige achtergrond van de beroepsbeoefenaren binnen ieder van beide benaderingen: enerzijds de economische, anderzijds de psychologische en adragologische disciplines. De eerste van deze benaderingen is aangeduid als de arbeidsmarkttheoretische. Hieronder wordt vooral het denken geschaard vanuit theoretische concepten betreffende de werking van de arbeidsmarkt. Een aantal theoretische kaders wordt behandeld: de 'human capital' theorie, de 'screeningshypothese', de theorie van de 'arbeidswachtrij' en de 'job matching' theorie. Binnen ieder van deze kaders worden veronderstellingen gehanteerd aangaande het type informatie dat bijdraagt tot een goede werking van de arbeidsmarkt.

De tweede benadering is aangeduid als de competentiegerichte. In deze benadering staan theorieën omtrent de psychische en psychosociale ontwikkeling van individuen centraal. Uitgegaan wordt van een gefaseerde ontwikkeling, waarbinnen ook de oriëntatie op keuzes aangaande de studie- en beroepskeuze zich fasegewijs ontwikkelt. De nadruk ligt op advisering bij en begeleiding van dit proces van gefaseerde oriëntatie, met de nadruk op 'begeleide zelfontdekking'. Binnen deze benadering wordt echter een verschuiving vastgesteld van denken in termen van advisering en begeleiding naar de ontwikkeling van competenties in verband met keuze en loopbaan (zgn. didactische model). Deze verschuiving wordt mede in verband gebracht met veronderstellingen omtrent de richting waarin de wereld van arbeid en beroep zich ontwikkelt.

\section{Convergentie en divergentie}

De laatste jaren lijkt zich weer een zekere convergentie van benaderingen af te tekenen, vooral in die zin dat de oriëntatie op de arbeidsmarkt weer een plaats krijgt binnen het denken over studie- en beroepskeuzevoorlichting. Tegelijkertijd tekent zich een andere divergentie af, namelijk tussen een denken vanuit enerzijds een betrekkelijk klassiek model van de arbeidsmarkt, anderzijds een anticipatie op fundamentele veranderingen in de werking van de arbeidsmarkt. Binnen de meer klassieke visie ligt de nadruk op transparantie van de arbeidsmarkt door middel van gerichte (met name prognostische) informatie, met als primair doel het vermijden van studie- en beroepskeuzes met mogelijk negatieve effecten, en op advisering en begeleiding met het oog op een in die zin verantwoorde keuze. Binnen de tweede visie ligt de nadruk op de toerusting van individuen tot handhaving op een arbeidsmarkt die steeds meer door onvoorspelbaarheid en veranderlijkheid wordt gekenmerkt en waar het steeds meer gaat om de 'arbeidsprestatie' in plaats van de 'arbeidsrelatie'.

Beide benaderingen hoeven echter niet met elkaar te conflicteren, doch leggen verschillende accenten. De arbeidsmarkttheoretische benadering benadrukt vooral het belang van de bevordering van de transparantie op de arbeidsmarkt. De competentie-gerichte benadering belicht daarentegen de condities waaronder dergelijke informatie zinvol kan worden overgedragen. Ook ten aanzien van de verwachte lange-termijnontwikkelingen hoeven beide benaderingen niet met elkaar in strijd te zijn. De in de competentie-gerichte benadering gesignaleerde ontwikkeling naar een flexibele arbeidsmarkt en erosie van de beroepenstructuur is slechts ten 
dele empirisch onderbouwd (bv. de flexibilisering van arbeidscontracten) en kent in hoge mate een futuristisch karakter. Van belang is hier om ook met feitelijk (arbeidsmarkt) onderzoek na te gaan welke ontwikkelingen zich voordoen en welke consequenties dit heeft voor de studieen beroepskeuzevoorlichting (bijvoorbeeld een mogelijke verbreding van de doelgroep naar werkenden, de ontwikkeling van indicatoren die meer de 'employability' belichten etc).

Ofschoon beide benaderingen elkaar dus niet uitsluiten en zelfs een convergerende tendens kan worden vastgesteld, bieden ze vanuit evaluatie optiek wel verschillende invalshoeken en accenten. Deze zullen in de volgende paragraaf nader worden uitgewerkt.

\subsection{Aangrijpingspunten voor evaluatie}

\section{Arbeidsmarkttheoretische benadering}

Samenvattend kan worden geconcludeerd dat in de arbeidsmarkttheoretische benadering thans de transparantie van de arbeidsmarkt centraal staat. Uitgangspunt is dat leerlingen die een studiekeuze moeten maken veelal onvoldoende zicht heben op de arbeidsmarktconsequenties die deze keuze heeft. Deze informatiekloof komt voort uit enerzijds een nog onvoldoende kennis van arbeidsmarktprocessen, maar vooral ook door het feit dat tussen de studiekeuze en de arbeidsmarktintrede veelal een periode van meerdere jaren zit. Hierdoor wordt de marktwerking, dat wil zeggen de interactie tussen de vraag op de arbeidsmarkt en de studiekeuze van leerlingen, belemmerd. Een voor-de-hand-liggende methode tot verbetering van de marktwerking is het transparanter maken van de arbeidsmarkt. Beïnvloeding geschiedt dan via de opleidings- en studiekeuzes van individuele leerlingen en studenten: "sturing zonder planning". Arbeidsmarktinformatie, in het bijzonder informatie over de arbeidsmarkt zoals die op het moment van verlaten van de te kiezen opleiding zal zijn (prognoses dus), draagt bij aan een optimalisering van die keuzes. Het hoeft hierbij niet alleen om een richtingskeuze te gaan. Gepercipieerde onzekerheid over de toekomstige arbeidsmarkt kan ook leiden tot de keuze voor een opleiding met een algemeen karakter, zodat zoveel mogelijk toekomstige arbeidsmarktmogelijkheden worden open gelaten. Borghans (1993) laat zien dat deze optimalisatie zowel op maatschappelijk als op individueel niveau winst oplevert. De beschikbaarheid van goede arbeidsmarktinformatie en -prognoses en een adequaat gebruik hiervan door leerlingen leidt er dan toe dat de verwachtingen over de arbeidsmarktmogelijkheden vaker dan voorheen zullen overeenkomen met de feitelijke situatie zoals die aangetroffen wordt bij de intrede op de arbeidsmarkt.

In principe is een dergelijke sturing op basis van arbeidsmarktprognoses ook mogelijk door een capaciteitsbeleid van de overheid. Nadeel van een dergelijk ingrijpen in het marktproces is echter dat een afgewogen studiekeuze niet alleen van arbeidsmarktfactoren afhangt, maar ook van individuele capaciteiten, voorkeuren en ambities. Bij een algemeen capaciteitsbeleid is het niet goed mogelijk deze afwegingen tot hun recht te laten komen. Verder kan een dergelijk 
capaciteitsbeleid ook averechtse werking hebben doordat het leidt tot een verstarring van de arbeidsmarkt (zie ook Borghans, De Grip en Willems, 1995).

Het bevorderen van een adequate studiekeuze door het transparant maken van de arbeidsmarkt legt de verantwoordelijkheid nadrukkelijk bij de leerlingen. Het beleid zorgt alleen voor een goede ondersteuning van deze studiekeuze door zorg te dragen voor voldoende informatie. Een consequentie hiervan is echter dat leerlingen afwegingen kunnen maken die niet sporen met afwegingen zoals de overheid deze zou willen maken.

Dat leerlingen op minder gunstige arbeidsmarktinformatie reageren met een aanpassing van hun opleidingskeuze is een centrale veronderstelling binnen deze benadering. Omdat in een op arbeidsmarkttransparantie gerichte benadering leerlingen zelf een afweging kunnen maken tussen diverse aspecten van hun keuze, valt uiteraard niet te verwachten dat zonder meer een keus gemaakt zal worden voor de opleiding met het meest gunstige arbeidsmarktperspectief. Een adequate studiekeuze vergt immers een afweging van zowel individuele interesses en capaciteiten als arbeidsmarktmogelijkheden. Hierdoor kan het zijn dat bepaalde leerlingen ondanks het feit dat ze op de hoogte zijn van het feit dat een opleiding een minder gunstig arbeidsmarktperspectief kent, toch deze richting kiezen, omdat deze negatieve aspecten ruimschoots gecompenseerd worden door inhoudelijke kenmerken van de opleiding.

Als echter de arbeidsmarkt mede een rol speelt in dit afwegingsproces, mag verwacht worden dat een verandering van het arbeidsmarktperspectief ook bij een bepaalde groep leerlingen tot een verschuiving van hun keuze zal leiden. Dit betreft de leerlingen die zich in hun afweging reeds rond de grens van wel of niet deze studie volgen bevonden.

In het navolgende worden de binnen deze benadering veronderstelde effecten verkend; bij deze effecten worden vervolgens effectmaten of criteriumvariabelen benoemd die de grondslag voor onderzoek kunnen vormen. Daarbij wordt een onderscheid gemaakt tussen macro- of maatschappelijke effecten en effecten op individueel niveau. Voor deze analyse is het echter belangrijk dat het effect van de arbeidsmarktinformatie hoofdzakelijk tot stand komt door beïnvloeding van individuele keuzes. Individuele effecten zijn dus tevens middel in het bereiken van de maatschappelijke effecten. Voor het onderzoek naar effecten gaat het echter om de individuele effecten als 'doel', niet als 'middel'.

\section{Maatschappelijke effecten}

Macro-effecten worden voorspeld in termen van een betere kwalitatieve aansluiting tussen vraag en aanbod en een geringere gevoeligheid van de arbeidsmarkt voor cyclische instabiliteit, het zogenaamde varkenscycluseffect. Deze effecten kunnen worden samengevat als een meer evenwichtige arbeidsmarkt. Daarnaast kan de noodzaak tot omscholing worden verminderd door een betere aansluiting tussen initieel onderwijs en arbeidsmarkt. Al deze effecten 
staan in functie van een vergroting van de effectiviteit van het onderwijssysteem en daarmee de versterking van de economische groei.

Onderzocht zou moeten worden welke maatschappelijke kosten onevenwichtigheden tussen studiekeuze en arbeidsmarkt met zich mee brengen. Daartoe zou aan de ene kant moeten worden nagegaan welke omvang de 'foute' studiebeslissingen hebben en aan de andere kant welke gevolgen deze verkeerde keuzes hebben. Bij het in kaart brengen van de omvang van foute beslissingen zou een onderscheid gemaakt kunnen worden tussen fouten als gevolg van verkeerde arbeidsmarktinformatie en fouten als gevolg van een verkeerde inschatting van de eigen voorkeuren en capaciteiten. Alleen de eerste categorie kan bestreden worden met het transparant maken van de arbeidsmarkt. Zoals Borghans (1993) laat zien moet bij een dergelijke analyse ook rekening worden gehouden met de effecten die op macroniveau optreden als leerlingen wel een juiste studiekeuze maken. De keuzefouten als gevolg van een verkeerde inschatting van persoonlijke voorkeur en capaciteit vragen om meer inspanningen op het klassieke studie- en beroepskeuzeterrein.

Bij de gevolgen van verkeerde keuzes kan gedacht worden aan productiviteitsverlies, een grotere behoefte aan aanvullende trainingen en een moeizamer intredeproces op de arbeidsmarkt. Met name de vergissingen als gevolg van verkeerde inschattingen van de eigen interesses en capaciteiten leiden mogelijk tot verhoogd studieuitval. Conform de analyses van Borghans (1993) kan een combinatie van omvang en effect een inzicht geven in de kosten van verkeerde beslissingen en daarmee de waarde van adequate arbeidsmarktinformatie en andere studie- en beroepskeuzevoorlichting.

\section{Individuele effecten}

Bij het verbeteren van de studiekeuze met betrekking tot de aansluiting op de arbeidsmarkt door een vergrote transparantie van deze arbeidsmarkt speelt uiteraard een rol welke factoren voor de leerlingen van belang zijn bij hun keuzeproces. Fundamenteler is echter welke facetten men achteraf, als men de arbeidsmarkt reeds heeft betreden van belang acht. De ex post evaluatie van de studiekeuze wordt in essentie gemaakt door de spijtvraag. Van een verkeerde studiekeuze kan immers worden gesproken als een individu op grond van de informatie en inzichten die hij verkrijgt nadat hij de arbeidsmarkt heeft betreden tot het inzicht komt dat hij beter een andere studie had kunnen kiezen. Door een dergelijke analyse te richten op de beoordeling achteraf wordt het mogelijk naast de tweedeling tussen arbeidsmarktaspecten en individuele capaciteiten en voorkeuren ook onderscheid te maken tussen enerzijds verkeerde beslissingen die ontstaan doordat een leerling reeds bij zijn studiekeuze het belang van bepaalde facetten erkende, maar zich vergiste door een verkeerde inschatting van de concrete omvang en anderzijds vergissingen doordat hij zich niet realiseerde dat bepaalde aspecten van een opleiding voor hem cruciaal zijn. Bij dit eerste facet kan gedacht worden aan een leerling die voor bepaalde opleiding koos omdat daar de werkgelegenheidsvooruitzichten bijzonder gunstig leken, terwijl deze achteraf tegenvielen. Bij het tweede facet kan als voorbeeld gewezen 
worden op studenten gezondheidswetenschappen, die pas na hun studie lijken te beseffen welk belang economische en juridische aspecten hebben in het functioneren van de gezondheidszorg. Door dit verschuivende inzicht lijkt er sprake te zijn van een systematische verschuiving van het belang dat aan deze vakken wordt gehecht gedurende de opleiding (zie Borghans en Bloemers, 1996).

Naast een analyse van individuele factoren die tot spijt van de studiekeuze leiden kan echter ook een analyse voor de keuzealternatieven voorafgaande aan de opleiding van belang zijn. Vanwege individuele capaciteiten en voorkeuren is het keuzedomein van leerlingen veelal beperkt. Dit impliceert dat een verhoogde instroom bij een bepaalde opleiding doorgaans tot reductie van de instroom bij een zeer specifieke groep leerlingen zal leiden. Voor beleid dat zich richt op het vergroten c.q. verkleinen van de interesse voor een richting is het daarom van belang om de groep leerlingen te kunnen traceren voor wie deze vernieuwde afweging relevant is. Hierdoor ontstaat een beter inzicht in de gevolgen die een dergelijk beleid zal hebben en ontstaat ook informatie aan welke groepen bepaalde voorlichting gericht moet worden. Ten slotte kan op deze wijze ook de potentiële omvang van bepaalde opleidingstrajecten worden vastgesteld.

\section{Competentiegerichte benadering}

Binnen de competentiegerichte benadering lijkt zich een zekere consensus af te tekenen op het punt van de onvoorspelbaarheid en veranderlijkheid van de toekomstige arbeidssituatie en de noodzaak hier de leerling/student op voor te bereiden. Ook wordt het potentieel effect van studie- en beroepskeuzevoorlichting volgens het klassieke model van informatieverstrekking in twijfel getrokken en worden vraagtekens gezet bij het 'rationele actor-model' dat wordt verondersteld binnen voorlichtings- en begeleidingsmodellen. De nadruk verschuift daarom in deze benadering van advisering en begeleiding met het oog op een specifieke opleidingsen beroepskeuze naar het ontwikkelen van de competenties om zich op de nieuwe arbeidsmarkt staande te houden; daarin staat het vermogen centraal om steeds opnieuw te kiezen, steeds opnieuw de bakens te verzetten, en om de eigen 'marktwaarde' op peil te houden.

Als aangrijpingspunt voor onderzoek naar de effecten van studie- en beroepskeuzevoorlichting is gekeken naar veronderstellingen aangaande effecten binnen deze benadering, in het bijzonder de effecten van arbeidsmarktinformatie. De meeste gevonden uitspraken betroffen echter datgene waarvan geen of weinig effect te verwachten is. Voornaamste implicatie van de theorie binnen deze benadering is dat van voorlichting tout court weinig effect te verwachten is, dus dat onderzoek naar dat effect als zodanig niet zinvol is. Wanneer voorlichting inhoudt het overdragen van informatie over studie- en/of beroepsmogelijkheden op momenten dat de institutie dat nodig acht (groepsvoorlichting, bezoek van open dagen, geroosterde gesprekken met de decaan e.d.) is er weinig effect te verwachten; gaat het initiatief van de leerling uit dan is het effect eerder te verwachten binnen het kader van een proces van geleidelijke inperking van keuze-alternatieven. 
Wat betreft het mogelijk effect van (arbeidsmarkt)informatie is een aantal veronderstellingen aangetroffen:

- informatie heeft vooral effect indien zij aansluit bij de 'levenstaken' in de onderscheiden ontwikkelingsfasen; voor iedere ontwikkelingsfase dient een ander informatiepakket te worden geboden.

- informatie heeft vooral effect op momenten waarop feitelijk gekozen moet worden; keuzes worden vaak uitgesteld tot institutionele regelingen ze onvermijdelijk maken.

- informatie heeft vooral effect indien afgestemd op de onderscheiden doelgroepen, c.q. op hun specifieke 'zone van acceptabele alternatieven'.

- informatie heeft vooral effect indien de kiezende over competenties beschikt voor het actief verwerven en verwerken van die informatie.

- informatie heeft vooral effect indien verweven met een leerproces gericht op het (verder) ontwikkelen van competenties op het terrein van het verwerken en verwerven van informatie en andere vaardigheden in relatie tot de eigen loopbaan.

\section{Mogelijke effectmaten}

Binnen de competentiegerichte benadering zijn mogelijke criteriumvariabelen:

* de houding van de leerlingen ten opzichte van hun entrée op de arbeidsmarkt (mate van anticipatie op flexibiliteit, waardenposities betreffende aanpassing, zelfverwerkelijking e.d., zingeving betreffende arbeid);

* de mate waarin en de wijze waarop leerlingen arbeidsmarktinformatie betrekken bij het formuleren van beroepswensen en bij feitelijk keuzegedrag op verschillende momenten in hun onderwijsloopbaan;

* de feitelijke ontwikkeling van een specifiek pakket competenties betreffende studie- en beroepskeuze en verdere loopbaan op diverse, naar leeftijd en/of onderwijsloopbaan bepaalde, momenten.

* de keuzemotieven van leerlingen op enige, institutioneel bepaalde, keuzemomenten als richtingkeuze VBO, vakkenpakketkeuze en keuze van vervolgopleiding of studie.

* de identiteitsontwikkeling op verschillende momenten, volgens het model van de 'zone van acceptabele alternatieven'.

Om te kunnen leiden tot uitspraken over effecten van studie- en beroepskeuzevoorlichting en in het bijzonder van arbeidsmarktinformatie zullen deze effectmaten hieraan moeten worden gerelateerd. Daarnaast dient een relatie te worden gelegd met achtergrondvariabelen betreffende de leerling (leeftijd, geslacht, sociaal-economische status, etniciteit, schoolloopbaankenmerken). De variabelen betreffende de studie- en beroepskeuzevoorlichting en arbeidsmarktinformatie zouden globaliter kunnen worden onderscheiden naar aanbod en inrichting en naar bereik. Aanbod en inrichting betreffen de wijze waarop leerlingen met studie- en beroepskeuzevoorlichting in breedste zin (inclusief gerichte ontwikkeling van competenties) in aanraking worden gebracht: typen materialen, spreiding over de leerweg, werkvormen enz. Ook intentionele voorlichting en begeleiding buiten de school (bij voorbeeld door het AOB, 
bedrijfsbezoeken en dergelijke) zou hierbij betrokken kunnen worden. Bereik betreft hier de mate waarin leerlingen feitelijk met arbeidsmarktinformatie en daaraan gerelateerd leeraanbod in aanraking komen. In aansluiting op het onderzoek van Boreham en Arthur ${ }^{3}$ zouden van de verschillende typen informatie de elementen van gebruik, betekenisgeving en toekenning van nut in het kader van keuzes kunnen worden onderscheiden. Indien ook gerelateerd aan effectmaten zou deze benadering een betrekkelijk compleet beeld kunnen verschaffen.

\section{Evaluatie van competenties}

Een specifieke mogelijkheid voor evaluatie is te onderzoeken of leerlingen de beoogde competenties aan het eind van het onderwijsloopbaan feitelijk hebben ontwikkeld en of dit samenhangt met een grotere vaardigheid in het verwerven en verwerken van relevante informatie.

Bij het onderzoeken van deze competenties kan zich echter een aantal problemen voordoen. Ten eerste zal het niet makkelijk zijn de bedoelde competenties eenduidig te operationaliseren. Het is denkbaar leerlingen te vragen of zij bij voorbeeld het gevoel hebben een duidelijke identiteit te hebben ontwikkeld (statisch), danwel of zij zich in staat voelen hun identiteit te ontwikkelen in relatie tot veranderende situaties om hen heen (dynamisch); het is ook denkbaar deze vaardigheden als persoonskenmerken in een persoonlijkheidsonderzoek te verpakken. In beide gevallen kunnen er vraagtekens worden gezet bij de construct-validiteit: wordt er echt gemeten wat in de theorie wordt gepostuleerd? Een andere benadering zou kunnen zijn de feitelijke competenties na te gaan in echte of gesimuleerde situaties die (aspecten van) het 'nieuwe beroepsleven' inhouden, dus een groot beroep doen op zelfsturend vermogen, keuzevaardigheid, flexibiliteit enz. Die benadering lijkt aantrekkelijker, maar kan op praktische gronden onhaalbaar lijken.

Ten tweede: indien al een meting mogelijk is, binnen welk model kan dan worden gezocht naar causale verbanden ter verklaring van het meetresultaat? De aangetroffen literatuur brengt de grotere nadruk op competenties in verband met veranderingstendensen binnen de beroepenwereld, maar een duidelijk tijdsperspectief ontbreekt. De uitgangssituatie waarmee zou kunnen worden vergeleken is niet eenduidig te bepalen; het gaat om het benoemen van langjarige ontwikkelingen die zich bovendien niet in alle sectoren, beroepsgroepen en regio's gelijktijdig en in precies dezelfde richting voordoen. Bovendien zijn uit de literatuur geen vroeger uitgevoerde vergelijkbare metingen bekend, dus er is geen vergelijkingsgrond. Transversale vergelijkingen binnen de onderzoeksgroep zouden wel verschillen tussen leerlingen uit verschillende milieus, tussen jongens en meisjes en tussen allochtone en autochtone leerlingen aan het licht kunnen brengen; aangezien de theorie specifieke verschillen voorspelt kan gedeeltelijke toetsing mogelijk zijn.

3. Boreham, N.C., T.A.A. Arthur, Information Requirements in Occupational Decision Making, School of Education, University of Manchester, Manchester 1993. 
Ten derde: ook indien meetresultaten beschikbaar zouden komen en verschillen tussen groepen leerlingen zouden blijken, in hoeverre zouden uitkomsten dan als effect van onderwijs kunnen worden geïnterpreteerd? Het onderwijs heeft bepaald niet het monopolie waar het gaat om informatie over de volwassen (beroeps)werkelijkheid; waarschijnlijk wordt het beeld dat leerlingen zich hiervan vormen in sterke mate medebepaald door informatie uit de onmiddellijke omgeving en, vooral, de media (Weerdenburg en Van der Aa e.a. ${ }^{4}$ ), terwijl voor oudere leerlingen vooral informatie in relatie tot de beroepsuitoefening een rol gaat spelen (Boreham en Arthur, ibidem). Onderzocht zou moeten worden of het praktisch mogelijk is de invloed van het primaire milieu, gerichte institutionele informatie en 'toevallige' informatie (vooral de media) te onderscheiden.

\section{Deelprogramma 1: Effecten}

In het onderstaande worden beknopt vijf onderzoeken gepresenteerd die kunnen bijdragen aan een gehele of gedeeltelijke toetsing van de in paragraaf 2.2 genoemde relaties tussen macro-economische variabelen, institutionele aspecten, leerlingkenmerken, informatie en de diverse effectmaten. Er wordt geen poging ondernomen tot een soort 'mastererdesign' dat alle denkbare relaties omvat; noch wordt het mogelijk geacht alle relaties met evenveel intensiteit te onderzoeken. Bij de keuze van de vijf onderzoeken is mede rekening gehouden met haalbaarheid, beheersbaarheid en financierbaarheid. Aan het eind van dit hoofdstuk wordt een schematisch overzicht gegeven van de 'dekking' van de in paragraaf 2.2 geschetste effectmaten door de vijf voorgestelde onderzoeken.

\subsection{Vijf voorstellen}

\section{a. Effect van arbeidsmarktinformatie: experimenteel design}

In dit experimenteel design wordt gepoogd het effect van verschillende typen arbeidsmarktinformatie te bepalen op het keuzegedrag van leerlingen. Dit wordt gerelateerd enerzijds aan hoe sterk de aanvankelijke voorkeur is voor een bepaald beroep en anderzijds de waardenhiërarchie ten aanzien van de verschillende keuzemotieven e.d.. In een experimentele setting kan worden onderzocht of systematische manipulatie van het informatieaanbod leidt tot systematische verschillen in de uiteindelijke keuze.

Wat betreft de proefpersonen zou kunnen worden gedacht aan een betrekkelijk homogene groep, bij voorbeeld de vierdejaars leerlingen HAVO en VWO van één of enkele scholen.

4. Weerdenburg, L.J.M., Behoefte, gebruik en waardering van studievoorlichting aan VWO-leerlingen, CSHOB, Enschede 1987;

Aa, R. Van der, W.H.A. Hofman, A. Vlaanderen, Determinanten van beroepskeuze in verschuivend perspectief, in: Dronkers, J., G.W. Meijnen, H. Dekkers (red.), Onderwijs en samenleving, SCO, Amsterdam 1991. 
Gezien het kostenaspect kan een dergelijk experiment slechts met een kleine groep worden uitgevoerd. Door met de leerlingen van één of enkele scholen te werken (in plaats van met een aselecte steekproef) wordt de variantie in de onderwijsachtergrond en de reeds verworven (arbeidsmarkt)informatie beperkt; hierdoor kunnen effecten zuiverder aan de 'treatment' worden toegeschreven. De keuze voor het vierde leerjaar HAVO/VWO hangt samen met het gegeven dat leerlingen dan, in verband met de vakkenpakketkeuze, toch reeds wat intensiever met hun toekomstplannen en -perspectieven bezig zijn.

Aangezien de proefpersonen op het moment van het experiment reeds specifieke voorkeuren en kennis over bepaalde beroepen hebben, en dit een vertekenende invloed kan hebben op de uitkomsten van het experiment, zal aan de proefpersonen worden gevraagd om een advies te geven aan een (denkbeeldige) kennis. Deze kennis heeft een bepaalde voorkeur voor een beroep. De proefpersoon dient een advies te geven op grond van de door de onderzoekers aangereikte informatie. Deze informatie betreft zowel aspecten met betrekking tot de kansen op werk voor dat beroep, de kwaliteit van het werk, als ook andere relevante beroepeninformatie. Bovendien wordt door de onderzoekers informatie verschaft hoe sterk de voorkeur van de "kennis" in kwestie is voor het betreffende beroep, alsmede wat zijn of haar capaciteiten voor het betreffende beroep zijn. Door systematisch de aard van de verstrekte informatie te variëren kan worden nagegaan wat het relatieve gewicht is van de verschillende typen informatie voor het uiteindelijke keuze die de proefpersoon maakt ("Wat zou jij in dat geval doen?"). Bovendien kan worden nagegaan wat de interactie-effecten zijn van de variabelen capaciteiten en voorkeur.

\section{b. De school als factor}

Een tweede onderzoek betreft de verschillen tussen scholen in de inrichting van de studie- en beroepskeuzevoorlichting, de keuzebegeleiding, het decanaat en de (al dan niet systematische) ontwikkeling van keuze- en loopbaanvaardigheden, en de mogelijk differentiële effecten van deze verschillen op het keuzegedrag van de leerlingen. Dit onderzoek valt dus uiteen in een beschrijvend en een effectbepalend deel.

Wat betreft het beschrijvend deel is het uitgangspunt dat over de wijze waarop de scholen de processen rond de diverse in de loop van de schoolloopbaan te maken keuzes inrichten niet veel bekend is. Door het ISOR is wel reeds een inventariserende studie uitgevoerd, waarover binnenkort gerapporteerd wordt. In dit onderzoek is ondermeer onderzocht of in de inrichting van de studie- en beroepskeuzevoorlichting en -begeleiding systematisch varianten zijn te onderscheiden en hoe deze varianten kunnen worden beoordeeld in het licht van een 'modelinrichting' volgens een aantal deskundigen ${ }^{5}$. Er zal zoveel mogelijk op de uitkomsten van dit

5. C.J. Vermeulen, Studie- en beroepskeuzevoorlichting en -begeleiding in het onderwijs, Onderzoeksvoorstel SVO 93126, ISOR Utrecht 1993. 
onderzoek worden voortgebouwd. Om drie redenen wordt aangenomen dat verdere beschrijving zinvol is:

1. (het belang van) arbeidsmarktinformatie lijkt in de ISOR-studie geen afzonderlijke aandacht te hebben gekregen. Nadere informatie over de wijze waarop scholen arbeidsmarktinformatie bij de diverse keuzeprocessen betrekken is echter, in het licht van de vraagstelling van dit onderzoeksprogramma, van groot belang.

2. dit geldt temeer in het licht van de recente overgang naar vraaggestuurde financiering van de externe ondersteuning van studie- en beroepskeuzevoorlichting, i.c. de dienstverlening van de RDC/AOB. Er zijn signalen dat scholen veel voorheen extern uitgevoerde taken nu zelf gaan uitvoeren. Op dit punt is actuele informatie van groot belang.

3. de recente aandacht voor de ontwikkeling van keuze- en loopbaancompetenties verdient de aandacht. Vraag is of de scholen hier reeds afzonderlijk aandacht aan besteden en of de gesignaleerde overgang naar een 'didactisch model' van studie- en beroepskeuzevoorlichting ook in de praktijk te documenteren valt.

Wat betreft het effectbepalende deel zou een meting kunnen plaatsvinden op een bepaald, in alle scholen van een bepaalde soort voorkomend, keuzepunt. De meting kan geschieden door middel van een vragenlijst; daarnaast is het denkbaar een aantal gestructureerde groepsgesprekken te doen plaatsvinden. De meting betreft in grote lijnen de geïnformeerdheid, de waardering van bepaalde categorieën informatie (binnen en buiten de school), de waardenhiërarchie ten aanzien van de diverse mogelijke keuzemotieven en de verwachtingen ten aanzien van arbeidsmarktkansen en -opbrengsten, persoonlijk succes e.d.. Verder vindt bepaling van een aantal leerlingkenmerken plaats. De uitkomsten worden zowel aan de leerlingkenmerken als aan de gemeten schoolkenmerken gerelateerd.

Dit type onderzoek vult in potentie een aanzienlijke lacune in de stand van de kennis aangaande studie- en beroepskeuzevoorlichting op. Toch moeten geen al te geprononceerde uitkomsten worden verwacht, vooral omdat geen al te grote systematische variantie in de 'onafhankelijke variabelen' wordt verwacht (geen duidelijk onderscheidbare inrichtingsvarianten) en omdat de schoolexterne informatiebronnen en invloeden moeilijk volledig kunnen worden beschreven noch systematisch gemanipuleerd. Daar staat tegenover dat, in vergelijking met het experimenteel onderzoek, de leerlinggebonden variabelen beter kunnen worden onderzocht. Bovendien geldt zowel voor de schoolvariabelen als voor de leerlinggebonden variabelen dat de lacunes in de stand van de kennis de uitkomsten ook als beschrijving en documentatie een grote waarde verlenen.

Het is mogelijk de beide onderzoeken 'effect van arbeidsmarktinformatie: experimenteel design' en 'de school als factor' logistiek en/of inhoudelijk met elkaar in verbinding te brengen, met name door de experimentele groepen ten behoeve van eerstgenoemd onderzoek te selecteren uit de scholen die deelnemen aan 'de school als factor'. Behalve kostenbesparing kan een belangrijk voordeel zijn dat in het experiment een betere beheersing van intermediaire variabe- 
len mogelijk is (met name de diverse schoolvariabelen en achtergrondkenmerken van de leerlingen), waardoor de kans op significante uitkomsten toeneemt.

\section{c. Dieptestudie betekenis en gebruik van informatie}

Dit voorstel betreft een dieptestudie naar de voorwaarden voor studie- en beroepskeuze op het vlak van de informatievoorziening, naar het model van de studie van Boreham en Arthur (1993). Zij gingen uit van de constatering dat leerlingen bij het maken van hun keuze kunnen beschikken over zeer veel en zeer diverse informatie, maar dat de benutting van deze informatie beperkt is. Hun onderzoeksvraag betrof het waarom van deze onvolledige benutting en de mogelijkheden tot een betere benutting.

Zij interpreteerden het keuzeproces daarbij als een proces van probleemoplossen. Informatie wordt in zo'n proces niet eenvoudig opgenomen en gereproduceerd maar actief verwerkt op basis van reeds aanwezige informatie: het individu construeert betekenis op basis van reeds aanwezige kennis. Deze betekenisgeving staat centraal in de dieptestudie. Het ging hen daarbij om vier categorieën informatie: informatie over het beroep, zelfkennis, de 'algemene kennisbasis' ("personal knowledge base") en een categorie 'autonome kennis', die individuen in toenemende mate zelf genereren op basis van zelfevaluatie. Een aantal beperkingen, op cognitief en affectief gebied, bij het verwerken en integreren van informatie werd verdisconteerd, waaronder de stijl van besluitvorming. Het onderzoek werd uitgevoerd door middel van diepteinterviews met een relatief kleine groep (144) met een zeer grote spreiding over het onderwijssysteem (van rond 16 jaar tot en met het volwassenenonderwijs). De proefpersonen werden bevraagd over ondermeer de beroepen die zij overwogen, de kennis die zij over die beroepen hadden, de bronnen van die kennis en de beoordeling van deze bronnen in termen van persoonlijke betekenis en waarde en van nut voor de persoonlijke besluitvorming. De uitspraken werden geanalyseerd in termen van 'persoonlijke constructen'. Het aantal proefpersonen en de grote spreiding lieten geen generaliseerbare uitkomsten toe; het onderzoek had een explorerend karakter. Wel kwam een aantal conclusies met een hypothetisch karakter naar voren, ondermeer betreffende de verschuiving in het gebruik en de waardering van de verschillende informatiebronnen naarmate leerlingen ouder worden en betreffende (verschillen in) stijlen van besluitvorming.

Voorgesteld wordt dit onderzoek qua methodologie in grote lijnen te repliceren. Daarbij zouden de hypothetische uitkomsten van de Engelse studie gedeeltelijk getoetst kunnen worden. Op minstens twee punten wordt een afwijkende opzet voorgesteld. Ten eerste zal arbeidsmarktinformatie als afzonderlijke categorie worden bevraagd, zowel met betrekking tot gestructureerde bronnen (voorlichting e.d.) als tot de 'toevallige' bronnen (mediaberichten, contacten e.d.). Ten tweede zal met een grotere groep proefpersonen worden gewerkt, meer geconcentreerd in een beperkter aantal schoolsoorten. Daarbij kan worden gepoogd een deel van de bevraging schriftelijk uit te voeren. Op deze wijze zou tot generaliseerbare uitspraken kunnen worden gekomen. 
Uiteraard zijn er raakvlakken met de leerlingbevraging in het onderzoek 'De school als factor' (zie boven). Er is echter een verschil in methode, met name het gebruik van half-gestructureerde interviews, waarbij de inbreng van de proefpersoon (aanvankelijke beroepswens) de verdere vraagstelling stuurt. Te overwegen is beide onderzoeken te relateren door de proefpersonen te selecteren uit de leerlingpopulatie van de scholen in het onderzoek 'De school als factor'. Naast logistieke voordelen levert dit de mogelijkheid op de uitkomsten mede aan schoolfactoren en aan de in het kader van dit onderzoek gedocumenteerde leerlingkenmerken te relateren.

\section{d. Het keuzeproces in de tijd: cohortonderzoek}

De in het voorgaande voorgestelde drie onderzoeken hebben allen bepaalde beperkingen. In dit verband worden genoemd: zij doen, in verschillende mate, geen recht aan het gefaseerde karakter van het oriëntatie- en keuzeproces, het uiteindelijk effect van dit proces, dus de uiteindelijke keuzes in en na het onderwijssysteem, blijft buiten beeld en zij bieden geen volledig zicht op het effect van de diverse achtergrondkenmerken van de leerlingen.

Als belangrijk kenmerk van het oriëntatie- en keuzeproces in verband met de overgang van onderwijs naar een specifieke opleiding of beroep komt in de literatuurstudie het gefaseerde karakter ervan naar voren. Het is meestal niet zo dat leerlingen kiezen op het moment dat dit, vanuit de rationaliteit van het volwassen en -beroepsmatig gezien- succesvol bestaan bezien, het meest voor de hand ligt; de keuzes worden dus ook lang niet altijd gemaakt na en in respons op specifieke voorlichtingsmomenten. Eerder is sprake van een langjarig proces van rijping (van de persoonlijkheid en in relatie daarmee van het beeld van het zelf als beroepsbeoefenaar), van oriëntatie, van toename van kennis omtrent de (beroeps)wereld, maar ook van geleidelijke afsluiting van mogelijkheden en verdere oriëntatie op een 'zone van acceptabele alternatieven' (model van Gottfredson, in o.m. Meijers ${ }^{6}$ ). Van dit proces is een aantal theoretische beschrijvingen en modellen voorhanden; hoe het echter in een concrete historische situatie verloopt kan variëren, omdat individuen de neiging hebben definitieve keuzes uit te stellen tot het door de institutionele setting bepaalde moment waarop ze onvermijdelijk worden.

In het experimentele onderzoek wordt dit aspect buiten haakjes gezet. In zowel het onderzoek naar de schoolfactor als in het onderzoek naar betekenis en gebruik van informatie kan het in zoverre worden betrokken dat in de onderzoeksgroep leerlingen op meerdere punten in het onderwijssysteem kunnen worden opgenomen, in samenhang met specifieke keuzemomenten (bij voorbeeld: tweede of derde leerjaar - einde basisvorming-, vierde leerjaar -vakkenpakketkeuze HAVO en VWO, keuze vervolgopleiding MAVO-, eerste leerjaar MBO - keuze specialisaties- ). De ontwikkeling van individuele leerlingen kan dus worden benaderd door transversale vergelijking tussen de verschillende groepen leerlingen in verschillende fasen. Deze benadering

6. Meijers, F., Determinatie en keuzebegeleiding in ROC's, een trendstudie, Delphiconsult/Max Goote kenniscentrum voor beroepsonderwijs en volwasseneneducatie, Amsterdam 1995. 
is beperkt, ondermeer doordat de keuzemomenten niet op alle scholen dezelfden zijn en 'tussentijdse' processen niet in beeld komen. Bovendien blijft het effect waar het uiteindelijk om gaat, namelijk de feitelijke studie- of beroepskeuze na verlaten van het onderwijs en de verdere loopbaan, buiten beeld.

Een tweede aspect dat in de voorgaande onderzoeken minder geprononceerd naar voren komt is het effect van de diverse leerlingkenmerken, met name ook de achtergrondkenmerken. In de literatuur blijken verschillen tussen jongens en meisjes, tussen leerlingen van verschillende sociaal-economische status, tussen leerlingen met autochtone en allochtone achtergrond en tussen leerlingen uit grootstedelijke en meer provinciale gebieden. Het is de vraag of de onderzoeksgroep in het onderzoek naar de schoolfactor voldoende groot zal zijn om al deze verschillen voldoende op mogelijke effecten te onderzoeken, met name ook op de uiteindelijke studie- en beroepskeuze en de verdere loopbaan.

De geëigende methode om onderzoeksvragen op dit punt te beantwoorden is een cohortonderzoek op basis van een omvangrijke steekproef. Een speciaal cohort voor dit doel kan echter op basis van kosten en de beperkte mogelijkheid tot belasting van de scholen uitgesloten worden geacht. Daarom is aansluiting bij een lopend cohortonderzoek overwogen. Een goede ingang bieden de cohorten VOCL-'89 en VOCL-'93; deze cohortstudies worden uitgevoerd ondermeer in het kader van de evaluatie van de basisvorming. Steeds wordt een instroomcohort gevolgd, dus een steekproef uit het eerste leerjaar VO (op basis van een steekproef van scholen). Van deze leerlingen wordt de schoolloopbaan gevolgd; ook is het de bedoeling de loopbaan nog tot enige jaren na uitstroom te volgen. Er wordt een schoolbelevingsschaal afgenomen en de leerlingen doen enige prestatietoetsen in het kader van de evaluatie basisvorming. Daarnaast vindt een ouderbevraging plaats. Parallel aan het cohort vindt een schoolkenmerkenonderzoek plaats, opdat kenmerken van de schoolloopbaan van de leerlingen mede uit kenmerken van de school kunnen worden verklaard.

Het is mogelijk extra variabelen bij dit onderzoek 'aan te haken'; van de kant van het CBS bestaat hiertoe, onder bepaalde condities, bereidheid. Aan het aspect van studie- en beroepskeuze wordt in de leerlingbevraging thans geen, en in het schoolkenmerkenonderzoek slechts uiterst beperkt aandacht besteed ${ }^{7}$. Te overwegen is:

* het toevoegen van een aantal variabelen aan het schoolkenmerkenonderzoek betreffende de inrichting van studie- en beroepskeuzevoorlichting, keuzebegeleiding en decanaat en de ontwikkeling van keuze- en loopbaanvaardigheden.

* een toegevoegde bevraging van de leerlingen, bijvoorbeeld in het vierde en zesde leerjaar, betreffende houdings- en kennisaspecten aangaande studie- en beroepskeuze.

* een secundaire analyse op de data betreffende de schoolloopbaan en het begin van de beroepsloopbaan enerzijds (standaardbevragingen) en bovengenoemde schoolkenmerken en leerlingkenmerken anderzijds.

7. CBS, codeboek VOCL'89, schooljaar 1994/'95, Heerlen z.d. 
Ten opzichte van het onderzoek naar de schoolfactor worden dus in essentie dezelfde variabelen bevraagd, echter aanmerkelijk globaler in verband met de grootte van de steekproef (kosten) en de combinatie met de standaardbevragingen (belasting van scholen en leerlingen). De winst is gelegen in de omvang van de steekproef en de uitstekende documentatie van achtergrond- en leerlingkenmerken, in de mogelijkheid tot het leggen van relaties met loopbaankenmerken (die bovendien niet retrospectief behoeven te worden bevraagd) en in het bijzonder in de mogelijkheid ook het 'uiteindelijk effect' (feitelijke keuzes na uitstroom en loopbaankenmerken buiten het onderwijs) in deze analyse te betrekken.

Aanhaken bij het lopende cohort vergt wel snelle besluitvorming. VOCL-'93 bevindt zich in het schooljaar 1996/'97 in het vierde leerjaar, dat in verband met de vakkenpakketkeuze HAVO/VWO en de keuze van vervolgonderwijs in VBO en MAVO zeer in aanmerking komt. VOCL'89 bevindt zich in het achtste jaar, dat wil zeggen deels in het hoger onderwijs, deels buiten het onderwijs; de laatste groep kan nog op de beroepsloopbaan worden bevraagd. In beide gevallen is snelle besluitvorming noodzakelijk om van deze mogelijkheden gebruik te kunnen maken.

\section{e. Macro-effect studie}

De basisgedachte achter het geven van arbeidsmarktinformatie aan studiekiezers is dat dit naast andere aspecten van de opleidingen - invloed zal hebben op de studiekeuze. Deze invloed van arbeidsmarktinformatie op de studiekeuze kan zoals in de eerdere onderzoeksvoorstellen, onderzocht worden naar aanleiding van het keuzegedrag van de leerlingen. Om de potentiële impact van informatie op het functioneren van de arbeidsmarkt in een macro-context te analyseren kan echter beter een analyse op grond van gegevens over het arbeidsmarktfunctioneren plaatsvinden. In het kader van een dergelijke macro-effect-studie zijn twee aspecten relevant. Ten eerste kan onderzocht worden in welke mate mismatch op de arbeidsmarkt voorkomt en in hoeverre deze mismatch samenhangt met onjuiste inzichten over de arbeidsmarktperspectieven van de genoten opleiding. Ten tweede kan bekeken worden in welke mate de totale hoeveelheid mismatch het arbeidsmarktfunctioneren belemmert, en op welke wijze dit tot uiting komt. Op beide aspecten wordt hieronder kort ingegaan.

De eerste vraag voor een macro-effect-studie betreft de omvang van mismatch op de arbeidsmarkt en met name in welke mate deze mismatch is toe te schrijven aan onvolledige arbeidsmarktinformatie. Een goed startpunt voor een dergelijke analyse is de zogenaamde spijtvraag. Uit de schoolverlatersenquêtes kan worden nagegaan welke leerlingen achteraf gezien liever een andere studie hadden willen volgen. Een dergelijke situatie wijst er dus op dat men ten tijde van de studiekeuze informatie miste die achteraf wel van belang wordt gevonden. Voor een gedeelte zal deze spijt overigens niet door de arbeidsmarktsituatie, maar door andere factoren, zoals inhoudelijke aspecten, worden bepaald. Er kan daarom een analyse worden uitgevoerd waarin wordt nagegaan in hoeverre het geprefereerde alternatief een betere arbeidsmarktpositie betekent dan de gevolgde opleiding. Impliciet kan hieruit het belang dat 
leerlingen hechten aan verschillende aspecten van hun baan, als ze eenmaal op de arbeidsmarkt zijn, worden gedestilleerd. Deze analyse geeft daardoor aan waar zich in het verleden vraag-aanbod-discrepanties hebben voorgedaan en laat zien welke rol verschillende aspecten van het werk (lage beloning, tijdelijk werk, werk beneden opleidingsniveau) spelen bij de beoordeling van de gemaakte keuze achteraf. Analyse van de door schoolverlaters geprefereerde alternatieven geeft bovendien inzicht in welke richting bepaald talent zich ontwikkelt indien niet voor een bepaalde richting gekozen wordt. Dat geeft inzicht in de verwantschap in voorkeuren voor bepaalde opleidingen.

De tweede vraag voor een macro-effect-studie betreft de mate waarin de arbeidsmarkt wordt belemmerd door studiekeuzes die onvoldoende door arbeidsmarktinformatie zijn onderbouwd. Mismatch kan per opleidingsrichting sterk variëren in de tijd door verschuivingen in vraag en aanbod. Hierdoor valt niet altijd te voorzien waar mismatch op zal treden. Hoewel vraagaanbod-discrepanties zullen wisselen tussen de opleidingsrichtingen zal er op geaggregeerd niveau wellicht toch sprake zijn van een vrij constante invloed. Op basis van een model dat de kans op vraag-aanbod-discrepanties verklaart, kan de macro-invloed van dergelijke arbeidsmarktdiscrepanties onderzocht worden. Door hierbij inzichten te betrekken uit onderzoek naar de uitingsvormen van vraag-aanbod-disrepenties (Wieling en Borghans, 1995) kunnen de totale 'kosten' van deze onevenwichtigheden worden geanalyseerd. Dit geeft een macro beeld van de waarde van adequate arbeidsmarktinformatie. Bij de 'kosten' van verkeerde studiekeuzes kan gedacht worden aan een toegenomen werkloosheid, slechtere beloning, werk onder het eigen opleidingsniveau etc, wat schoolverlaters zullen ervaren bij aanbodoverschotten. Het spiegelbeeld hiervan wordt gevormd door zaken als openstaande vacatures, hoge loonkosten, en onvoldoende opgeleid personeel, dat werkgevers in het geval van aanbodtekorten zullen ervaren. Een betere aansluiting tussen onderwijs en arbeidsmarkt kan aan beide kanten de gevolgen van mismatch verkleinen.

\subsection{Dekking effectmaten}

In het onderstaande worden de diverse effectmaten (afhankelijke variabelen) en veronderstelde relaties tussen variabelen, zoals onderscheiden in paragraaf 2.2, kort herhaald. Vervolgens wordt aangegeven in welke onderzoeken een bepaling van deze effectmaten en relaties is voorzien. De indeling verwijst naar de subparagrafen in paragraaf 2.2.

\section{Maatschappelijke effecten}

1. geringere werkloosheid (frictie- en structurele)

2. snellere vervulling van vacatures (geringere kosten)

3. betere kwalitatieve aansluiting vraag - aanbod

4. geringere gevoeligheid arbeidsmarkt voor cyclische instabiliteit

5. hoger onderwijsrendement, beperking volume onderwijs

6. versterking economische groei en internationale competitiviteit 
7. geringere kans op werkloosheid

8. grotere kans op beloningsniveau in overeenstemming met opleiding

9. grotere kans op studiekeuze 'zonder spijt'

10. grotere kans op realisatie van wensen en ambities

11. verschillende reactie op prognose in relatie tot talent en motivatie

12. werkloosheid, inkomen, spijt enz. in relatie tot individuele kenmerken

\section{Competentiegerichte benadering}

13. informatie effectiever indien aansluitend op 'levenstaken'/ontwikkelingsfasen

14. informatie effectiever op momenten waarop moet worden gekozen

15. informatie effectiever indien afgestemd op doelgroep

16. informatie effectiever in relatie tot beschikbaarheid van competenties

17. informatie effectiever indien verweven met ontwikkeling van competenties in relatie tot de loopbaan

18. mate van anticipatie op flexibiliteit

19. waardenposities betreffende arbeidsvereisten

20. zingeving van arbeid

21. feitelijk betrekken van arbeidsmarktinformatie bij successieve keuzes

22. ontwikkeling van competenties betreffende studie- en beroepskeuze en loopbaan

23. keuzemotieven op de successieve keuzemomenten

24. identiteitsontwikkeling in relatie tot ontwikkelingsfasen

\section{Evaluatie van competenties}

25. competenties in relatie tot flexibele arbeidssituaties

26. verschillen in competentieontwikkeling in relatie tot maatschappelijke achtergrond

27. onderscheidbaar effect van institutionele informatie ten opzichte van primair milieu en toevallige informatie

In het onderstaande wordt globaliter aangegeven in welke van de vijf onderzoeken deze effectmaten en relaties aan de orde komen. Dit overzicht is niet meer dan indicatief. De uiteindelijke 'dekking' kan nog door de nadere operationalisatie van de voorstellen in de offertes worden beïnvloed.

experiment

school als factor

betekenis en gebruik info. 131415161718192021 (24) (26) 27

cohort

7891012181923

macro effect

12378912 
Dit globale overzicht toont dat de meeste onderscheiden effectmaten meer of minder uitgebreid worden 'gedekt'. Vooral de variabelen in direct verband met de informatieoverdracht (13 - 21) zijn goed vertegenwoordigd. De meeste van deze variabelen worden in twee of drie onderzoeken op verschillende wijze geoperationaliseerd, in hoofdlijn onderscheiden naar survey (schriftelijke bevraging met de nadruk op relaties met schoolvariabelen en leerlingkenmerken) en diepteonderzoek (experimenteel danwel dieptebevraging naar individuele betekenisgeving en gebruik).

Enige variabelen komen niet in de onderzoeken terug: 4, 5, 6 en 25; enige worden slechts ten delen geoperationaliseerd (tussen haakjes in het overzicht): 24 en 26. Wat betreft 4, 5 en 6: deze liggen buiten het bereik van de analyse van het arbeidsaanbod in de macro effectstudie. Voor 24 zou een longitudinaal diepteonderzoek vereist zijn; de veronderstellingen op dit punt zijn echter reeds eerder getoetst. 25 zou een simulatie van arbeidsprocessen vergen. 26 tot slot kan worden benaderd voorzover aspecten van de competentieontwikkeling in de verschillende onderzoeken aan de orde komen.

\section{Deelprogramma 2: Veranderende omgeving}

\subsection{Aanleiding}

Een aantal constateringen in het rapport van de literatuurstudie geeft aanleiding tot onderzoek niet alleen naar de effecten van studie- en beroepskeuzevoorlichting en arbeidsmarktinformatie maar ook naar de zich wijzigende sociaal-economische en institutionele context hiervan.

Een eerste constatering is dat de tegenstellingen in het denken over studie- en beroepskeuzevoorlichting, onstaan in de jaren '70, geleidelijk aan het oplossen zijn. In de literatuur werden in zeer grove lijnen twee hoofdstromen in het denken ter zake geconstateerd (paragraaf 2.1). Een eerste stroming, ontstaan binnen de beroepsgroep van studie- en beroepskeuzevoorlichters in de jaren '60 en '70, oriënteert zich vooral op de individuele keuze in relatie tot aanleg en voorkeur enerzijds en kenmerken van beroepen anderzijds. Een tweede stroming, ontstaan in respons op de economische problematiek van de jaren '80, neemt als uitgangspunt het streven naar een transparante arbeidsmarkt als voorwaarde voor individuele keuzes die mede op arbeidsmarktkansen zijn gebaseerd. Tussen deze beide, aanvankelijk zowel naar institutionele inbedding als naar visie sterk gescheiden, stromingen tekent zich echter convergentie af, in de zin van een toenemende erkenning van het belang van arbeidsmarktrelevantie als één van de keuzecriteria en van competentieontwikkeling (keuze- en loopbaancompetenties) in plaats van het klassieke voorlichtingsmodel. Tegelijkertijd kan worden geconstateerd dat deze convergentie in denken nog niet tot een eenduidige verandering in de voorlichtings- en begeleidingspraktijk heeft geleid. In die zin kan van een zekere impasse worden gesproken.

Een tweede constatering is dat zich geleidelijk een andere tegenstelling zou kunnen aftekenen, namelijk tussen het denken over studie- en beroepskeuzevoorlichting (binnen beide genoemde 
stromingen én tot op zekere hoogte binnen het convergerend denken) en de werkelijkheid van het beroepsleven zoals die zich in de nabije toekomst lijkt te gaan ontwikkelen. Het is de vraag of het begrip 'beroep', enigszins eenduidig gedefinieerd naar enerzijds bepaalde beroepsinhouden en anderzijds min of meer stabiele arbeidsverhoudingen, niet zijn langste tijd heeft gehad. De vraag is of de steeds snellere ontwikkeling van de beroepsinhouden en de toenemende flexibilisering van de arbeidsverhoudingen niet tot een wezenlijk andere definitie van het keuzeprobleem, en dus van de keuzevoorlichting en -begeleiding, zullen leiden. Zoals reeds aangegeven hoeft dit niet op gespannen voet te staan met het streven naar competentieontwikkeling en een grotere transparantie. Probleem is vooral dat op dit punt veel speculatie en weinig zekerheid bestaat.

Een derde constatering, in het literatuurrapport overigens slechts terzijde aangestipt, is dat er zich een crisis aftekent in de institutionele voorzieningen voor studie- en beroepskeuzevoorlichting. Een deel van de regionale dienstencentra of AOB's verkeert in ernstige problemen, tot en met het faillissement, vooral als gevolg van de overgang naar vraaggestuurde financiering. Andere 'aanbieders' van diensten ter zake tekenen zich nog niet duidelijk af. In hoeverre en hoe de scholen de diensten, die zij niet meer bij het RDC/AOB 'kopen', zelf uitvoeren is nog niet duidelijk. Te verwachten is dat zich geleidelijk een nieuwe institutionele structuur rond studie- en beroepskeuzevoorlichting zal gaan aftekenen. Overeenkomstig de beroepensociologisch georiënteerde theorie van Pere $^{8}$ kan worden aangenomen dat deze institutionele structuur, en in verband daarmee de belangen van de betrokken beroepsgroep(en), een zelfstandige invloed zal uitoefenen op aard en inhoud van de studie- en beroepskeuzevoorlichting en -begeleiding.

Deze constateringen leiden tot de conclusie dat het veld van studie- en beroepskeuzevoorlichting de komende tijd de nodige verschuivingen te zien zal geven; verwachtingen omtrent een nieuwe evenwichtssituatie zijn in hoge mate ongewis. Nader inzicht in de uitkomsten van deze veranderingsprocessen is van groot belang voor alle betrokkenen binnen de institutionele structuur rond studie- en beroepskeuzevoorlichting en voor de overheid als mede verantwoordelijke voor deze structuur. Het gaat immers om de ontwikkelingen die directe gevolgen kunnen hebben voor de behoeften aan, en daarmee ook de markt voor, arbeidsmarktinformatie ten behoeve van studie- en beroepskeuzevoorlichting, en dus voor de bijdrage van deze informatie aan de transparantie van de arbeidsmarkt. Het is van het grootste belang te verkennen hoe deze transparantie onder zich wijzigende omstandigheden kan worden gehandhaafd en zelfs verbeterd, hoe het effect van deze informatie op het keuzeproces van leerlingen en studenten kan worden geoptimaliseerd en hoe deze informatie het beste in verband kan worden gebracht met andere vormen van keuzevoorlichting en -begeleiding die zich onder druk van de zich wijzigende omstandigheden zullen ontwikkelen. Verkenning van het veranderingsproces is met andere woorden van grote strategische betekenis voor alle betrokken partijen. De aard van de

8. Pere, H.M., tussen arbeidsmarkt en individueel welzijn; een historische analyse van de beroepskeuzevoorlichting in Nederland vanuit beroepensociologisch perspectief, Educaboek, Culemborg 1986. 
veranderingen is daarenboven van verstrekkende reikwijdte: het gaat om hoofdstromen met een uitwerking op vele beleidsterreinen, hier nader belicht voor het op zich al veelomvattende aspect van de overgang van onderwijs naar beroepsleven. De uitkomsten kunnen dus een bijdrage leveren aan de beleidsvorming op diverse terreinen.

\subsection{Conceptueel kader}

Voorlopig wordt uitgegaan van een model waarin het aanbod en de benutting van arbeidsmarktinformatie wordt bepaald door de interactie tussen vier categorieën actoren, die ieder op eigen wijze reageren op de druk vanuit de maatschappelijke en economische omgeving:

* de gebruikers: leerlingen en studenten; in toenemende mate ook ouderen in verband met de noodzaak tot voortdurende heroriëntatie;

* de producenten van arbeidsmarktinformatie: LDC, ROA, evt. anderen;

* de intermediairen: alle instituties die de arbeidsmarktinformatie bij de gebruikers moeten brengen, dus scholen, RDC's/AOB's, RBA enz.

* de overheid en andere beleidsbepalende instanties, met in dit verband o.m. een rol in de vertaling van omgevingsdruk naar institutionele veranderingen.

Voorlopig worden zes globaal gedefinieerde veranderingsprocessen onderscheiden waarvan grote invloed op de uitkomsten van dit krachtenveld wordt verwacht. Drie betreffen veranderingen in de omgeving, in het bijzonder het beroepsleven; drie betreffen het institutionele kader zelf en de krachtsverhoudingen daarbinnen.

Aan de kant van het beroepsleven gaat het om:

* ontwikkelingen in de inhoud van de arbeid: globaliter de kwalificatiebehoefte, waarbij het hier echter niet zozeer gaat om de aard van de nieuwe behoeften alswel om de veranderingssnelheid en -richting, om de mate van dynamiek. Daarbij dienen verschillen tussen segmenten van de arbeidsmarkt in het oog te worden gehouden.

* ontwikkelingen in de structuur van beroepen: hier gaat het dan vooral om de ontwikkeling in de vorm waarin de vraag naar arbeid zich organiseert, waarbij globaliter een ontwikkeling wordt voorzien van 'beroepen' naar 'klussen' (afgebakende werkeenheden van bepaalde duur en omvang).

* ontwikkelingen in de arbeidsverhoudingen: hierbij gaat het niet primair om de arbeidsrechtelijke aspecten alswel om de tendens tot flexibilisering: de relatieve toename van tijdelijke arbeidsverhoudingen, de ontwikkeling van 'werknemer' naar 'werkondernemer'; ook binnen vaste arbeidsverhoudingen de toenemende druk tot flexibiliteit (functie-mobiliteit, snellere verandering van functieinhouden, projectmatig werken e.d.).

Als 'intermediaire variabele' in dit hele complex van omgevingsveranderingen zou ook de demografische ontwikkeling in ogenschouw moeten worden genomen, met name de vergrijzingstendens en daarmee de veranderende marktwaarde van nieuwe intreders in de arbeidsmarkt.

Aan de kant van het institutioneel kader gaat het om: 
* ontwikkelingen binnen onderwijsinstellingen: de inrichting van voorlichting, advisering, begeleiding en competentie-ontwikkeling in brede zin. Hier is vooral interessant de wijze waarop het onderwijs inspeelt op veranderingen in de omgeving en in de externe dienstverlening. Wat betreft het laatste gaat het vooral om de gevolgen van de vraaggestuurde financiering, in het bijzonder het internaliseren danwel uitbesteden van (tot voor kort afzonderlijk gefinancierde) diensten. Deze gevolgen worden ondermeer geanalyseerd vanuit de optiek van Pere (ibidem), nl. de autonome invloed van de belangen van de beroepsgroep op de vervulling van relevante functies. In hoeverre ontwikkelt zich binnen het onderwijs een beroepsgroep wier belangen het 'aanbod' van studie- en beroepskeuzevoorlichting mede stuurt?

* ontwikkelingen binnen de externe dienstverlening: de instellingen die ten behoeve van studie- en beroepskeuzevoorlichting specifieke diensten leveren. Hierbij gaat het vooral om de RBA, de RDC/AOB en om concurrerende diensten die als gevolg van de vraaggestuurde financiering naar voren zouden kunnen komen. Ook hier geschiedt de analyse mede vanuit beroepensociologisch perspectief: welke invloed hebben deze ontwikkelingen op het 'aanbod' en het bereik en effect hiervan?

* ontwikkelingen binnen het complex van levenslang leren: algemeen wordt aangenomen dat actuele en te verwachte ontwikkelingen in het beroepsleven leiden tot een toenemende noodzaak van voortdurend leren en voortdurend kiezen. Aan te nemen is dat de institutionele structuur hierop zal inspelen. Ook hier is de vraag vooral naar de invloed hiervan op het 'aanbod' en het effect. Daarnaast is het bedrijfsleven hier in beeld, zowel in voorwaardelijke zin (b.v. ontwikkeling verlofregelingen) als in de rol van 'aanbieder' met eigen belangen.

\subsection{Onderzoeksvoorstellen}

\section{a. Veranderende omgeving}

Dit onderzoek omvat het complex veranderingen in de omgeving, in het bijzonder in de sfeer van het beroepsleven in relatie tot demografische ontwikkelingen, die in de toekomst de context van de studie- en beroepskeuzevoorlichting zullen bepalen. Voorgesteld wordt dit onderzoek te richten op het uitwerken van enige scenario's, waarin op basis van verschillende veronderstellingen de mogelijke effecten van deze veranderingstendensen in hun onderling verband worden verkend. De nadruk zou daarbij kunnen liggen op de mogelijke gevolgen van de diverse vormen van flexibilisering. Onder het, meer pakkende dan wetenschappelijk gefundeerde, begrip 'flexmarkt' zijn in het rapport van de literatuurstudie de mogelijke gevolgen samengevat van de veranderingsprocessen op het vlak van de arbeidsverhoudingen, de inhoud van de arbeid en het aanbod van arbeid. Flexibilisering staat op het moment sterk in de belangstelling, zowel waar het gaat om de actuele ontwikkelingen als om de verwachtingen voor de toekomst. Wat betreft die toekomst worden soms opzienbarende verwachtingen uitgesproken, waarbij het verband met de waarneming van feitelijke trends niet altijd even helder is. 
Gezien de mogelijk zeer verreikende consequenties van de flexibiliseringstendensen, niet alleen voor de studie- en beroepskeuzevoorlichting, wordt een grondige documentatie voorgesteld van zowel empirisch materiaal, als van deskundigenoordelen. Aan deze documentatie kunnen veronderstellingen worden ontleend die de grondslag kunnen vormen voor de uitwerking van enige scenario's en voor een beoordeling van de waarschijnlijkheid van deze scenario's als toekomstige context van studie- en beroepskeuzevoorlichting.

Dit onderzoek omvat in hoofdlijn:

* analyse van primaire en secundaire databestanden, uitgevoerde trendstudies en kwantitatieve prognoses gericht op de empirische onderbouwing van flexibiliseringstendensen. Daarbij dient ook onderzocht te worden of er verschillen zijn naar sector, beroepsgroep, bedrijfsgrootte en regio.

* interviews met deskundigen: werkenden in de sfeer van de arbeidsbemiddeling, personeelsvoorziening, technologische ontwikkeling e.d. die aspecten van flexibilisering in de praktijk kunnen waarnemen en op mogelijke consequenties kunnen beoordelen. Hierbij dient een zekere spreiding naar sector en bedrijfsgrootte te worden betracht .

* literatuurstudie betreffende flexibilisering

* uitwerken van twee of meer scenario's op basis van in de verkenningen aangetroffen veronderstellingen; verkenning van de mogelijke consequenties van deze scenario's voor de studie- en beroepskeuzevoorlichting; beoordeling van de waarschijnlijkheid van deze scenario's en van de bedoelde consequenties. Mogelijk kan de uitwerking en beoordeling van de scenario's geschieden in samenwerking met een panel deskundigen, bij voorbeeld in een Delphi-achtige opzet.

\section{b. Veranderend institutioneel kader}

In dit deelonderzoek staat de ontwikkeling van het institutioneel kader van studie- en beroepskeuze centraal, zowel binnen onderwijsinstellingen als binnen dienstverlenende en intermediaire instituties (vooral RBA, RDC/AOB en nieuwe concurrerende diensten). Invalshoeken zijn de gevolgen van de vraaggestuurde financiering en de gevolgen van de diverse institutionele veranderingen binnen deze instellingen (bij voorbeeld ROC-vorming) voor de praktijk van de studie- en beroepskeuzevoorlichting. Een hypothese is dat, als gevolg van de afbouw van de geoormerkte financiering, de schaalvergroting en professionalisering in het onderwijs en de expliciete taakstelling ter zake in de Wet Educatie en Beroepsonderwijs (WEB), een geleidelijke verinnerlijking van de studie- en beroepskeuzevoorlichting binnen de onderwijsinstellingen zal optreden. Ook personele belangen kunnen daarbij een rol spelen, bij voorbeeld voorkomen van boventalligheid. De vraag is wat de gevolgen hiervan voor de praktijk van studie- en beroepskeuzevoorlichting zullen zijn. Zal zich bij voorbeeld opnieuw een min of meer onderscheidbare beroepsgroep van keuzebegeleiders en competentie-ontwikkelaars ontwikkelen, die vanuit het belang van domeinhandhaving een min of meer stabiele en uitsluitende definitie van deze activiteit kan geven (Pere, ibidem), of zal dit complex van functies min of meer amorf in het geheel van de onderwijsactiviteiten opgaan? Elk van beide uitkomsten zou vergaande 
consequenties hebben voor de wijze waarop met name arbeidsmarktinformatie zinvol kan worden aangeboden. Ook de mogelijke respons op externe druk (flexibilisering) kan verschillend zijn.

Op meer inhoudelijk vlak is een belangrijke vraag of de in de literatuur voorziene verschuiving van het klassieke model van studie- en beroepskeuzevoorlichting, met de nadruk op informatieaanbod, individueel onderzoek en keuzebegeleiding, naar een meer didactisch model zich inderdaad voor zal doen. In dit model ligt de nadruk op de ontwikkeling van competenties in verband met te maken keuzes, zowel bij de overgang van onderwijs naar beroepsleven als in de latere loopbaan. De vaardigheid tot het actief verwerven, raadplegen en evalueren van informatie staat daarbij centraal. Onderzocht zal worden of deze veranderingen te documenteren zijn en of ze kunnen worden geduid met behulp van bovengeschetste verandering van model. Ook zal een globaal overzicht van de invulling van de competentieontwikkeling binnen de verschillende vormen van onderwijs worden nagestreefd.

Voorgesteld wordt dit onderzoek uit te voeren door middel van literatuurstudie en van interviews met sleutelfiguren binnen de betrokken instituties. Voorgesteld wordt een vast panel samen te stellen van scholen ( bij voorbeeld enige scholengemeenschappen VBO/AVO/VWO en enige $R O C ' s$ ) en van AOB's. De leden van dit panel worden enige keren bevraagd gedurende de periode van gefaseerde overdracht van de financiering van studie- en beroepskeuzevoorlichting van de AOB's naar de scholen (dit geschiedt in fasen, voor wat betreft het VBO, AVO en VWO tussen 1997 en 2000, voor wat betreft de ROC's in 1997 en 1998). Daarnaast worden de panelleden één maal per jaar samengebracht om over de gevolgen van de institutionele veranderingen van gedachten te wisselen.

Het verband met het onderzoek 'de school als factor' uit deelprogramma 1 dient daarbij te worden bewaakt. Ten opzichte van dit onderzoek heeft de panelstudie een bredere verkennende en ideeëngenererende opzet en een longitudinale opzet, waarbij de aandacht vooral is gericht op de veranderingstendensen.

\section{c. Internationale vergelijking}

Voor een goede beoordeling van de 'grote trends', de ontwikkeling van de 'flexmarkt' en de verschuiving naar een competentiegericht model in het onderwijs, kan het vertekenend zijn alleen de Nederlandse situatie te onderzoeken. Zeker waar het gaat om de ontwikkeling van de institutionele structuur en de invloed daarvan op het aanbod en de functie van arbeidsmarktinformatie zullen de ontwikkelingen waarschijnlijk een forse nationale component hebben. Globale verkenning van vergelijkbare ontwikkelingen in enige andere landen kan tot een genuanceerder oordeel over deze ontwikkelingen en hun strategische implicaties leiden. Ook internationaal vergelijkend onderzoek en publicaties van internationale organisaties (OECD, EU en evt. andere) kunnen hier van belang zijn. Voorgesteld wordt vergelijkend onderzoek uit te voeren in België (Vlaanderen), Duitsland en één of meer andere landen 
(gedacht is aan Zweden, de USA en Frankrijk). Globaliter kan worden gedacht aan een eerste ronde interviews met enige sleutelfiguren met het oog op een eerste oriëntatie, aansluitende literatuurstudie en tot slot nog enige meer gerichte interviews. Daarnaast kan een verkenning van de beschikbare vergelijkende literatuur worden uitgevoerd.

\section{Synthetiserend rapport}

In het synthetiserend rapport worden ten eerste de uitkomsten van de onderzoeken in de beide deelprogramma's in een samenhangend kader geplaatst. Ligt in deelprogramma 1 de nadruk op de relaties tussen (inrichting van) studie- en beroepskeuzevoorlichting, arbeidsmarktinformatie en effecten, in deelprogramma 2 staat de ontwikkeling van de omgeving en het mogelijk effect hiervan centraal. In de synthese worden veranderingen in de maatschappelijke en economische omgeving opgevat als randvoorwaardelijk voor de individuele en maatschappelijke effecten, bedoeld in deelprogramma 1. De institutionele structuur (onderwijs en intermediaire voorzieningen) leent zich weliswaar voor politieke beïnvloeding, maar in het kader van dit onderzoek is dit niet de primaire invalshoek; de conclusies richten zich op de studie- en beroepskeuzevoorlichting en de arbeidsmarktinformatie in een veranderende context.

Met het oog op dit samenhangend kader zou een literatuurstudie moeten plaatsvinden, vooral gericht op mogelijk verklarende theoretische modellen (theorievorming betreffende de werking van de arbeidsmarkt, organisatie- en beroepensociologische modellen e.d.). Mogelijk kan, op kwalitatief niveau, een oordeel worden gegeven over de mate van aansluiting tussen de verschillende theoretische modellen, toekomstscenario's en feitelijk waargenomen ontwikkelingen.

Ten tweede zou, in het licht van het theoretisch kader, een evaluatie van de bevindingen plaats kunnen vinden, resulterend in uitspraken over strategische beslissingen en beleidslijnen van relevante instituties gericht op optimale inzet van arbeidsmarktinformatie in het kader van studie- en beroepskeuzevoorlichting, gegeven de verschillende verwachtingen aangaande de omgeving en de institutionele context. Te overwegen is ook dit evaluatief onderdeel onderzoeksmatig te onderbouwen, bij voorbeeld in de vorm van een Delphi-achtig onderzoek of een gerichte consultatie van deskundigen op basis van de concept-uitkomsten.

\section{Literatuur}

AA, R. Van der, W.H.A. Hofman, A. Vlaanderen, Determinanten van beroepskeuze in verschuivend perspectief, in: Dronkers, J., G.W. Meijnen, H. Dekkers (red.), Onderwijs en samenleving, Amsterdam, SCO 1991.

Boreham, N.C., T.A.A. Arthur, Information Requirements in Occupational Decision Making, School of Education, University of Manchester, Manchester 1993.

Borghans, L., Educational Choice and Labour Market Information, ROA, Maastricht 1993.

Borghans L., A. de Grip en E. Willems, Methodology of the ROA information system on occupational groups and types of education, ROA-W-1995/1E, Maastricht 1995. 
Borghans L. en I. Bloemers, De arbeidsmarkt voor de maatschappij-wetenschappelijke stroom bij gezondheidswetenschappen, ROA-R-1996/7, Maastricht 1996.

Meijers, F., Determinatie en keuzebegeleiding in ROC's, een trendstudie, Delphiconsult/Max Goote kenniscentrum voor beroepsonderwijs en volwasseneneducatie, Amsterdam 1995.

Meijers, F., Rendeert informatie? Over de mogelijkheden en de grenzen van studie- en beroepskeuzebegeleiding in het onderwijs, in: Rendement van opleidingen en allocatie van arbeid, OSA nr. 191994.

Meijers, F., Van kiezen en gekozen worden; grenzen en mogelijkheden van beroepskeuzebegeleiding, in: Handboek studie- en beroepskeuzebegeleiding, Samson H.D. Tjeenk Willink, Alphen aan den Rijn 1993.

Pere, H.M., Tussen arbeidsmarkt en individueel welzijn; een historische analyse van de beroepskeuzevoor lichting in Nederland vanuit beroepensociologisch perspektief, Educaboek, Culemborg 1986.

Vermeulen, C.J., Studie- en beroepskeuzevoorlichting en -begeleiding in het onderwijs (onderzoeks voorstel SVO 93126), ISOR Utrecht 1993.

Weerdenburg, L.J.M., Behoefte, gebruik en waardering van studievoorlichting aan VWO-leerlingen; Enschede, CSHOB 1987.

Wieling M. en L. Borghans, Discrepancies between Demand and Supply and Adjustment Processes on the Labour Market, ROA-RM-1995/4E, Maastricht 1995. 